\title{
The mismeasure of nature: the political ecology of economic valuation of Tiger Reserves in India
}

\author{
Ajit Menon ${ }^{1}$ \\ Nitin D. Rai \\ Madras Institute of Development Studies, India \\ Ashoka Trust for Research in Ecology and the Environment, India
}

\begin{abstract}
The Indian state has conserved tigers by establishing reserves that are governed as a form of fortress conservation. Residence and local uses in these tiger reserves are often criminalized. It is in this context that we critique recent neoliberal attempts to estimate the economic value of ecosystem services from tiger reserves. Proponents of valuation argue that it will not only provide a justification for the reserves, but also recognize the importance of ecosystem services for human well-being. We use a political ecology approach to argue that economic valuation is never a benign tool, but is situated in wider institutional contexts that favor certain actors over others. In India, protected areas are being valued even as people living within them are being evicted and their use of the forest restricted. We draw from fieldwork in the Biligiri Rangaswamy Temple Hills of Karnataka and conversations with Soligas. We ask how nature is made legible and who benefits from such legibility? We suggest that economic valuation can hide complex human-nature relationships and undermine different ways of knowing and 'valuing' landscapes.
\end{abstract}

Key Words: tiger reserves, Karnataka, economic valuation

\section{Résumé}

L'État indien a préservé les tigres en établissant des réserves gérées comme une forme de conservation de la forteresse. La résidence et les utilisations locales dans ces réserves de tigres sont souvent criminalisées. C'est dans ce contexte que nous critiquons les tentatives néolibérales récentes d'estimer la valeur économique des services écosystémiques issus des réserves de tigres. Les défenseurs de l'évaluation estiment que cela ne fournira pas seulement une justification des réserves, mais reconnaîtra également l'importance des services écosystémiques pour le bien-être humain. Nous utilisons une approche d'écologie politique pour affirmer que l'évaluation économique n'est jamais un outil bénin, mais se situe dans des contextes institutionnels plus larges qui favorisent certains acteurs par rapport à d'autres. En Inde, les zones protégées sont valorisées alors même que les personnes qui y vivent sont expulsées et que leur utilisation de la forêt est restreinte. Nous nous basons sur des travaux sur le terrain dans les collines du temple Biligiri Rangaswamy, dans le Karnataka, et sur des conversations avec les peuples Soligas. Nous demandons comment la nature est rendue lisible et à qui profite cette lisibilité? Nous pensons que l'évaluation économique peut masquer des relations complexes entre l'homme et la nature et saper les différentes façons de connaître et de «valoriser» les paysages.

Mots-clés: réserves de tigres, Karnataka, évaluation économique

\footnotetext{
${ }^{1}$ Dr. Ajit Menon, Professor, Madras Institute of Development Studies, 79 2nd Main Road, Gandhinagar, Adyar, Chennai 600020, India. Email: ajit1112 "at" gmail.com. Dr. Nitin D. Rai, Fellow, Ashoka Trust for Research in Ecology and the Environment, Royal Enclave, Sriramapura, Jakkur Post, Bangalore 560064, India. Email: nitinrai "at" atree.org. We thank all those people who gave us time in BRT to discuss their views on economic valuation of tiger reserves. Nitin would also like to put on record his gratitude to C. Madegowda and the Soliga Abhivriddhi Sangha for their support over the many years in facilitating his research in BRT. This work was supported by the Research Council of Norway (grant number 250975).
} 


\section{Resumen}

En India, el estado ha conservado a los tigres por medio del establecimiento de reservas que son gobernadas a manera de conservación fortaleza. El uso local y la residencia en estos reservas de tigres, son prácticas frecuentemente criminalizadas. Es en este contexto, hacemos una crítica a los recientes intentos neoliberales por estimar el valor económico de los servicios de ecosistemas de las reservas de tigres. Quienes proponen esta valoración argumentan que esto no solamente proveerá una justificación para dichas reservas, sino que reconoce la importancia de los servicios de ecosistemas para el bienestar humano. Por medio de un acercamiento desde la ecología política, discutimos que la valoración económica nunca resulta un instrumento benigno, pues está situada en contextos institucionales más amplios que favorecen a unos actores sobre otros. En India, las áreas protegidas están siendo valoradas incluso aunque las población que vive en ellas está siendo desalojada y el uso que daban al bosque, restringido. El estudio se basa en trabajo de campo realizado en las colinas del templo Biligiri Rangaswamy, de Karnataka, además de conversaciones con los soligas. Las preguntas que hacemos tienen que ver con cómo la naturaleza se hace legible y quién se beneficia de tal legibilidad. Sugerimos que la valoración económica puede esconder complejas relaciones humano-naturaleza y desvirtuar diferentes maneras de conocer y "valorar" los paisajes.

Palabras clave: reservas de tigre, Karnataka, valuación económica

\section{Introduction}

We sat with Acchuge Gowda outside his house in Yerakinagadde colony, located in the Biligiri Rangaswamy Temple Tiger Reserve (henceforth BRT) in India. We told him about a report entitled Economic valuation of tiger reserves in India: a value+ approach (Verma et al. 2015, henceforth Verma Report), and he interrupted us to ask "why is the government 'valuing' tiger reserves"? We had come to BRT with a summary of a shorter article (Verma et al. 2017) on tiger valuation based on the original report, in order to ask Soligas (an Adivasi community that constitutes the majority of the population in BRT) what they felt about the valuation of services in tiger reserves. Instead of answering Acchuge Gowda's question, we asked him for his opinion. Without hesitation he said that if the government was to value the forests of BRT it was because it wanted to justify the eviction of Soligas. Acchuge Gowda's fear was based on what he had heard Indian Prime Minister Narendra Modi say on the radio in 2017: that 750 villages were going to be relocated from tiger reserves across the country in order to conserve the tiger (Panthera tigris tigris).

Acchuge Gowda's contention that the government would only want to value BRT so as to relocate Soligas raises two critical issues:

1) how does the historical and institutional context in which economic valuation takes place shape its possible outcomes?

2) what types of value might be privileged in the course of economic valuation?

Addressing these issues moves us away from seeing economic valuation merely as a technical tool to ensure that nature is properly measured and hence valued. It also allows us to more rigorously analyze the empirical workings of neoliberal conservation, as opposed to its conceptual underpinnings, as Huff and Tanui (2017) urge us to do.

In this article, we define neoliberal conservation as a governmentalizing strategy aimed at conservation "through the creation of incentive structures intended to influence individuals' use of natural resources in the interest of biopower by altering the cost-benefit ratio of resource extraction so as to encourage in situ conservation." (Fletcher 2010: 176). To understand economic valuation and neoliberal conservation through a governmentality framework, we argue as Bresnihan (2016) does, that it is necessary to view the institutional and regulatory mechanisms of neoliberalism as 'tactics' by which governments solve socio-economic and environmental challenges. Then we examine its environmental justice impacts instead of presupposing that it is only a strategy of capital accumulation. We take as our starting point Dempsey and Robertson's suggestion to "avoid portrayals of neoliberalism in which capitalism rolls out coordinated and univocal state policy effecting a wholesale commodification of nature" (2012: 759). Instead we examine the ontology and epistemology of economic valuation, so as to evaluate its possible outcomes. Equally importantly, we examine the institutional and historical context in which tiger reserves are being economically valued. 
Doing so in the context of the BRT requires taking a discursive approach to economic valuation and hypothesizing how this discourse might translate on the ground if economic valuation is used to commodify ecosystem services, and payment for ecosystem services (PES) schemes are then implemented. At present, economic valuation of tiger reserves in India is a technical exercise to calculate the total economic value of six such reserves, made by academics and conservation bureaucrats. ${ }^{2}$ The argument put forward is that calculating the total economic value will result in capturing the hidden values of many natural resources that remain unaccounted for and that improve human well-being. The institutional context of BRT (not one of the six tiger reserves studied) is that it has a long history of coffee plantations and fortress conservation. Our main focus, therefore, is to see how this history of sovereign governmentality where the state usurps the rights of its citizens in protected areas through a fortress conservation approach (Fletcher 2010: 178) might shape the economic valuation of BRT based largely on a critical analysis of what Soliga leaders felt about economic valuation. By doing so, we hope to elaborate on the two issues raised above so as to imagine what type of a forest economic valuation might make legible in the BRT and who the main beneficiaries would be of such a forest. The article is divided into seven sections. Following this introduction, we situate economic valuation in a wider discussion of the political ecology of neoliberal conservation. Section 3 discusses Soliga fears about economic valuation in a brief history of Soliga dispossession due both to the expansion of coffee plantations and the emergence of a protected area in BRT. In Section 4, we highlight the reasons Soligas are skeptical about economic valuation of tiger reserves and their counter-narratives and explanations about forest degradation and conservation. Section 5 explores the social and ecological implications of neoliberal conservation while Section 6 puts forward a possible framework through which we can judge the outcomes of economic valuation so that it is cognizant of environmental justice concerns. In the conclusion, we summarize our arguments and reiterate our main concerns.

\section{The political ecology of neoliberal conservation}

If we look at neoliberal conservation as a tactic through which to solve environmental and socioeconomic challenges as Bresnihan (2016) suggests, then we must first unpack its logic. Neoliberal conservation, broadly speaking, privileges economic incentives, markets and the infusion of private capital into conservation. In India, neoliberal conservation is making an appearance in the form of carbon forestry/REDD+ implemented under the Clean Development Mechanism (CDM), ecotourism and PES schemes. India has the second highest number of CDM projects in the world (Aggarwal 2019: 36). The schemes are based on a principle of substitution, namely that development and its adverse ecological implications in one area can be compensated for in another area. Aggarwal (2019) argues, however, that these newly forested sites are composed mostly of fast-growing tree varieties and that these have adverse impacts on local communities in terms of their crop, fodder and fuelwood needs. Moreover, if carbon is the focus, the main beneficiaries would be those trading in carbon. Ojha et al. (2019) similarly show that the contemporary carbon-centric discourse for forest conservation hides other ecological and livelihood benefits. The increasing focus on neoliberal conservation over-rides other ways of interacting with and knowing forests.

Similar arguments have been put forward with regard to initiatives aimed at incentivizing the conservation of existing biodiversity. Munster and Munster (2012) argue that large ginger (Zingiber officinale) farmers in Wayanad, Kerala, a hilly region in south India, were the prime beneficiaries of ecotourism. It would be fair to say that for the most part the beneficiaries of nature tourism would be those who can invest significant amounts of capital. Given this empirical evidence from India, it is not surprising that critics of neoliberal conservation argue that its underlying premise is that "natures" can only be saved through their submission to capital. Büscher (2012: 29) contends that capitalist markets are unable to resolve their own ecological contradictions. Fletcher and Büscher (2017) refer to PES strategies that identify neoliberal approaches as both the problem and the solution to ecological crises as a "PES conceit" and conclude that this must be addressed when we "confront the broader neoliberal power structures" (2017: 224).

\footnotetext{
${ }^{2}$ In July 2019 the authors released the results of the valuation of an additional ten tiger reserves. The report is available at https://projecttiger.nic.in/WriteReadData/PublicationFile/IIFM_Tiger\%20Report_2019_Final_HR_Binder_260719compressed_compressed.pdf
} 
Economic valuation of tiger reserves is the latest neoliberal proposal for conservation in India. Economic valuation is premised on the belief that conservation and development are potentially complementary (Gomez-Baggethun and Ruiz-Perez 2011). This is so because economic valuation, through stated and revealed preference methods, makes it possible to capture the monetary value of non-marketed ecosystem services. Capturing these hidden values, it is claimed, is important not only to emphasize the ecological costs of unbridled economic growth, but equally to make the case that conservation provides ecosystem services that enhance human well-being. As suggested above, once resources are valued, those who use them might have a greater stake in conserving them as well.

In 2005, the Millennium Ecosystem Assessment (MEA 2005) mainstreamed economic valuation and the ecosystem services approach. The MEA divided ecosystem services into provisional, regulatory, supporting and cultural services and highlighted how they improved human well-being. In 2006, the Nature Conservancy and World Wildlife Fund, in partnership with Stanford University, established the Natural Capital Project (http://www.naturalcapitalproject.stanford.edu). This was followed in 2010 by the United Nations Environment Programme's (UNEP) The Economics of Ecosystems and Biodiversity initiative (TEEB http://www.teebweb.org). All these center-staged valuation of 'natural capital.' India was not to be left behind. In 2011, the Ministry of Environment and Forests, Government of India, launched a new initiative, in collaboration with TEEB, to value its biodiversity and natural capital. The government was explicit in stating that natural resources should be translated into wealth and that local communities would benefit.

The Verma Report (2015) has not only a global genealogy, therefore, but a national one too. Its logic is similar to the above-mentioned approaches - value tiger reserves so as to capture their total economic value, which not only would provide an economic logic to conservation, but also improve local human well-being through recognizing the value of non-marketed ecosystem services and potentially through PES to those who partake in the conservation of particular services. Verma and Negandhi (2018: 4) further justify the valuation of services, stating that the protection that has been given to tiger reserves "has resulted in the increased flow of a wide array of ecosystem services, which are actually used by various stakeholders, without appreciating their use values" (2018: 5). This echoes the early writings on PES and valuation, including Wunder (2005) who said that valuation helps secure ecosystem conservation and restoration. Implicit in the valuation approach is the belief that the intrinsic value of nature is inadequate to preserve it - what is needed is an instrumental economic logic as well.

Valuing tiger reserves is premised on the belief that they comprise a number of ecosystem services. The Verma Report (2015) mentions 25 such ecosystem services, including agriculture, timber, non-timber forest products (NTFP), pollination and carbon sequestration, with different beneficiaries at different scales. Tiger reserves are made legible through valuing these ecosystem services, which, it is assumed, will help improve human well-being.

Economic valuation and tiger conservation by default become technical exercises. Experts assume center stage: ecologists who understand the workings of the ecosystem and, more significantly, economists who use valuation techniques to ascertain the 'true' economic value of ecosystem services. Not surprisingly, the valuation team appears to have largely spoken to these experts and not to local people who reside in tiger reserves. The identification of services itself is determined by these experts. This fits well with scientific forestry that has for the last two hundred years, with a few exceptions, seen forest management as the preserve of the Forest Department. As we illustrate later, Soliga views of the forest and its 'services' are often very different from the expert view on value (Verma and Negandhi 2018: 4).

The ecosystem services approach is often blind to the wider institutional context in which services are situated (Barnaud and Antona 2014). The mix of resources and the beneficiaries of ecosystem services depend on the institutional context and priorities of particular management regimes. However, when it comes to policymaking, more often than not, economists take the institutional context for granted, treating it as 'pristine' nature that must be preserved or even recreated, forgetting that different imaginations of the forested landscape are possible. Paying attention to the institutional context also reveals who benefits from the services. Making nature legible by valuing ecosystem services, in other words, does not guarantee improvements in human wellbeing. In a context where tiger reserves are inviolate, how can local communities benefit from ecosystem services? While Chattre et al. (2012) argue that tenure security for local communities is likely to incentivize them more to support conservation efforts in the context of REDD+, the vexing question that remains is 
conservation of what? As we illustrate later, Soliga leaders we met had a very different idea about what a forested landscape should look like.

Economic valuation of ecosystem services and the estimation of 'natural capital' has also been critiqued by conservationists as being instrumental and often based on Walrasian economics. ${ }^{3}$ Writing in the pages of Conservation Biology, economists Gowdy and colleagues ask:

...should assigning the correct price for ecosystems and biodiversity be the sole focus of environmental valuation and public policy? The methodological requirements of the Walrasian system demand that everything valuable in a good or productive input must be captured in a single price so that the "calculating machine" of the market can establish the pecking order of priorities. .... In this sense conservation becomes entirely dependent on valuation methodology" (Gowdy et al. 2010: 1444).

In a trenchant critique of valuation, ecologist Douglas McCauley writes that some people:

...believe that the best way to meaningfully engage policy-makers driven by the financial bottom line is to translate the intrinsic worth of nature into the language of economics. But this is patently untrue - akin to saying that civil-rights advocates would have been more effective if they provided economic justifications for racial integration. (McCauley 2006: 28)

Redford and Adams (2009: 797) say that an ecosystem services approach needs to be drawn into conservation "with great care." Yet despite critiques from both the social and natural sciences valuation has come to occupy a prominent place in conservation policy.

\section{A conservation genealogy of sovereignty and neoliberal governance}

BRT is one amongst several protected areas (PA) that are part of a large area of forest that ranges across the three states of Karnataka, Tamil Nadu and Kerala (Figure 1). This large area measuring nearly 5,000 km² was declared the Nilgiri Biosphere Reserve in 1986. It was identified by the Ministry of Environment and Forests as a major area of importance for the conservation of the tiger, with the result that five of the protected areas in this region have been declared tiger reserves (three in Karnataka and two in Tamil Nadu).

In the past, the Mysore Maharaja and British officers hunted in these preserves while the forest departments of colonial and independent India logged timber there. The colonial government also leased forests located in the higher reaches of BRT to a Scottish planter named Randolph Morris for the production of coffee in 1867 (Rice 1897). Morris extended his control subsequently through additional grants. Post-independence, Morris' plantation was subdivided into four plantations which are now owned by Indian companies. The total area under coffee plantations held by the four companies today is about 550 ha, a large portion of which is leased from the Forest Department (Coffee Board 2016).

The growth of coffee plantations and timber production describes a history of extraction and accumulation. The colonial state and estate owners employed local people who lived and farmed within the forest, namely Adivasi communities such as the Soligas and non-Adivasi communities such as the Badagas. Soligas narrate how the Forest Department used them to raise timber plantations and prevent fires from spreading through plantations. The Forest Department allowed Soligas to cultivate between the timber saplings and in adjoining areas until the forest was grown, after which they were moved to a different area to raise more plantations after trees had been harvested. Li (2010) has described how colonial forest policy was targeted at denying Adivasi groups in India ownership of land in order to use them as labor for forestry operations. For sustenance they were made to depend on forestland for cultivation and on sale of forest produce when available. The colonial government's targeted denial of land rights and ownership to Adivasis resulted in their dispossession even as the state and private actors accumulated through timber and coffee production.

\footnotetext{
${ }^{3}$ Marie-Esprit-Léon Walras (1834-1910) pioneered elements of general equilibrium theory in economics.
} 
This history of disenfranchisement continued after Independence. In 1974, the Karnataka government notified the BRT forests as a wildlife sanctuary and banned all customary practices such as swidden agriculture, hunting and the use of fire (Rai et al. 2019). The Karnataka Forest Department relocated Soligas from their settlements in the various parts of the forest into villages in the periphery of the reserve and along roads. Even as the Forest Department razed Soliga settlements to the ground and families moved to colonies outside the forest, it also settled many families close to the coffee plantations so as to ensure a continued supply of labor for the plantations and to assist the state with forest management.

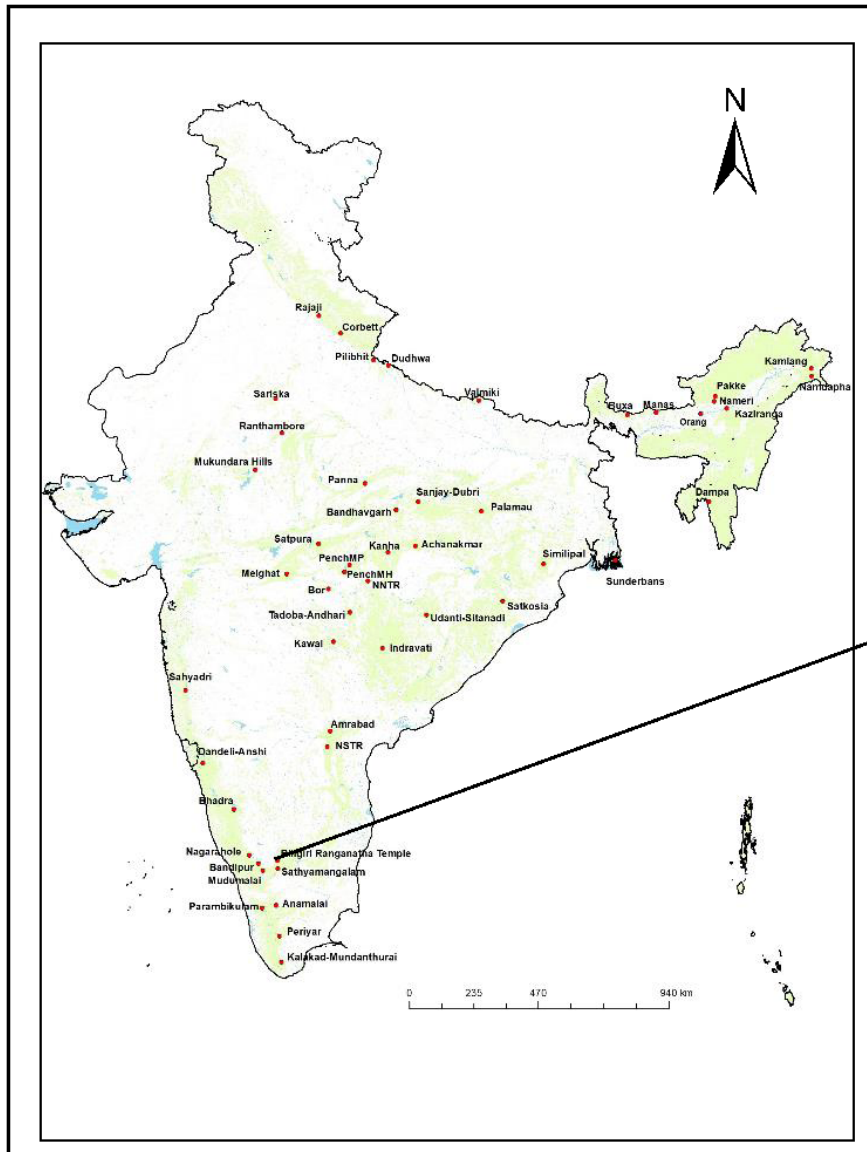

(A)

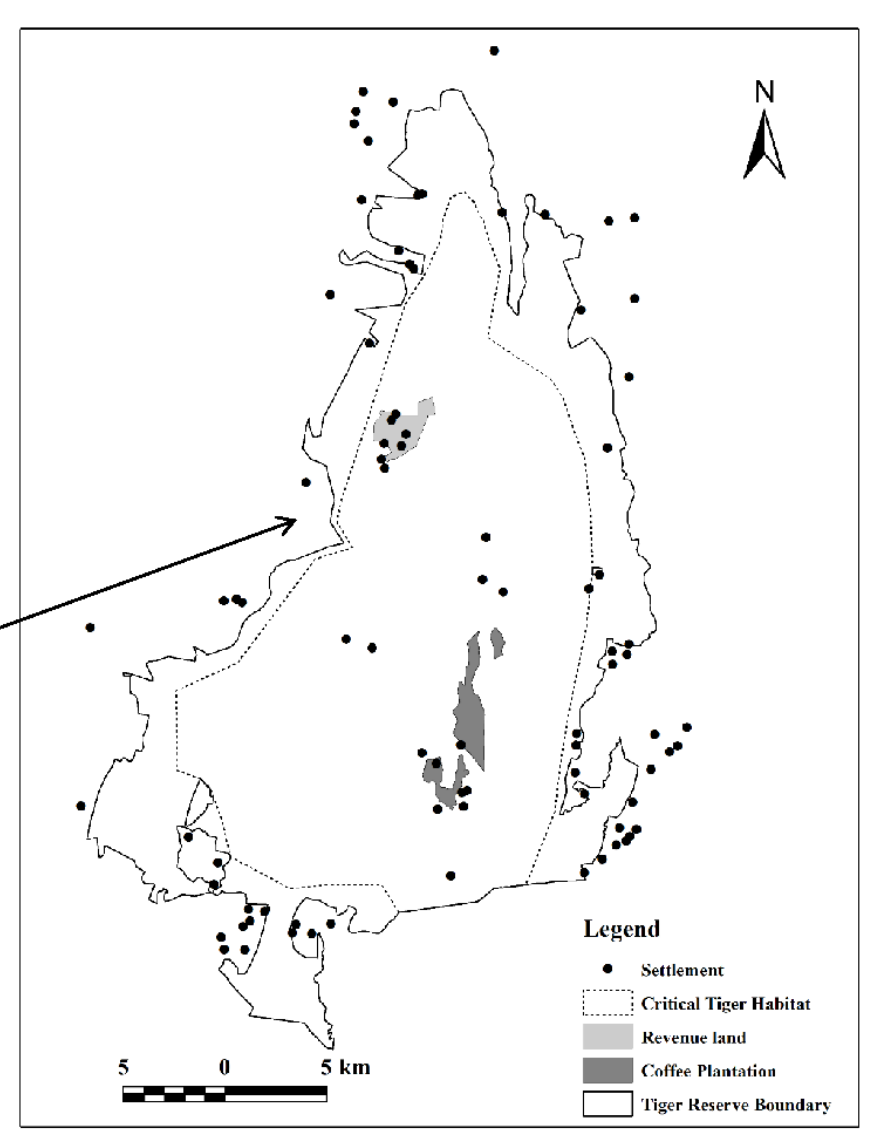

(B)

Figure 1: (a) The locations of the fifty tiger reserves in India and (b) Map of the Biligiri Rangaswamy Temple Tiger Reserve.

Source: (a) Modified from https://projecttiger.nic.in/content/247_1_map-showing-tigerreserve.aspx and (b) ATREE Eco-informatics Centre.

Soligas faced fresh trouble in BRT in the new millennium. In 2002 the Wildlife (Protection) Act (WLPA) was amended to ban the collection of NTFP, which greatly affected the livelihoods of Soliga households who depended on the sale of NTFP to augment their incomes (Madegowda 2009). Soligas increasingly depended on wage labor in the coffee plantations within BRT and in agricultural farms outside the forest. Barely had the dust settled on the NTFP ban issue when, in January 2011, the government declared BRT a tiger reserve. The WLPA, which lays down the legislative process for wildlife conservation in India, mandates, as mentioned above, that tiger reserves have an inviolate core area, or critical tiger habitat (CTH), 
from which all people have to be relocated. Although no clarity exists on how many families the government intends to relocate from the CTH, an official estimate suggests the government will relocate 34 villages from BRT (Lok Sabha 2013). There is continuing pressure on Soligas in BRT to relocate outside the tiger reserve and restrict their use of the forest. This pressure continues even though over forty village sabhas in BRT have claimed and received community and individual forest rights under the Scheduled Tribes and Other Traditional Forest Dwellers (Recognition of Forest Rights) Act, 2006 (henceforth the FRA). ${ }^{2}$ Their continued alienation from the forest is a direct result of the territorial control by the state for tiger conservation.

The NTCA's circular of March 2017, which mandated that no rights, whether individual rights to cultivable land or community rights to forest, could be granted under the FRA in tiger reserves, is the government's most recent move to deny rights and alienate people who live in them. Although this order was revoked a year later under pressure from the Ministry of Tribal Affairs, these repeated attempts to erode the FRA are a clear statement of NTCA's intent to not allow people to live in or depend on the forests within tiger reserves. It would be fair to say, therefore, that the Soligas have for the most part experienced a form of fortress conservation or what Fletcher (2010: 177) calls "sovereign environmentality." How does economic valuation, which is a form of a neoliberal environmentality, add to the historical marginalization of Soligas? We addressed this question based on our understanding of the institutional, historic and social contexts gained over 15 years of research in BRT. This long-term research was augmented by two stints of fieldwork in BRT in 2017 for this article, during which we conducted interviews in BRT with 14 Soliga male elders. These unstructured interviews were conducted after sharing a translated version of the Verma et al. (2017) article with each of the interviewees. We introduced to each of the respondents the concept of economic valuation and described the various ecosystem services that were being valued so they could better understand economic valuation of ecosystem services.

\section{Retrieving Soliga concerns about economic valuation}

Recounting the history of dispossession helps us to contextualize how valuation of tiger reserves might pan out in the Indian context and in BRT, and therefore understand the skepticism of Acchuge Gowda and others regarding valuation. It is important to recall that the main claim of the Verma Report was that the hidden value of ecosystem services would be retrieved and that doing so would increase human well-being, including that of local people (Verma et al. 2015). The argument goes that by making nature legible through mapping out the ecosystem services of tiger reserves, the importance of particular ecosystem services to local people can be ascertained.

In what follows, we argue that making nature legible will not benefit local people due to the wider institutional context of protected area management. Economic valuation in India has assumed importance in a context where inviolate tiger reserves are on the increase. Local use of ecosystem services such as NTFP is being discouraged, not valued, as in some cases eco-development schemes are being promoted to wean local communities off their dependence on forest resources. A careful reading of the Verma Report (2015) suggests that its primary purpose is to highlight the value of tiger reserves in monetary terms as opposed to ways in which these financial benefits can be shared with local communities. During a conversation, two elder Soliga men, Karekethe Gowda and Hanume Gowda expressed concern that valuing tiger reserves is the government's way of emphasizing the economic value of tiger reserves and hence denying Soligas their entitled claims under the FRA (under the FRA, Soligas have been granted rights to cultivate and use the forest for NTFP, grazing, worship, fishing, and customary management).

Many Soliga leaders we spoke to pointed out that valuation was a way to exclude their people as the Forest Department had always claimed that Soligas were responsible for forest degradation. They believed that valuation would be used to tighten conservation practice. They pointed out to us, however, that their presence in the forest was enough to protect it and that valuation efforts were not therefore necessary for conservation of the forest. Placing a money value on ecosystem services, they felt, would separate them from the forest and allow it to be sold off to private players such as tourism operators. They believed that valuing services was linked to the continued attempt to marginalize them.

Soligas were also highly skeptical about the Forest Department's approach to conservation. Who after all, many asked, had lived with and nurtured forests for hundreds of years? Who continues to have deep cultural 
ties to these forests? Soliga after Soliga we met expressed their consternation that the Forest Department has never included them in discussions about forest management. Equally, they were quick to ask us whether Madhu Verma and her team had engaged with local communities while valuing the six tiger reserves in the course of their work. These concerns have been echoed by scholars who fear that economic valuation and commodification of resources undermine indigenous knowledge (Aggarwal 2019: 37)

Another concern with making ecosystems legible through valuing individual services is that it tells you little about possible alternative scenarios (Lele and Srinivasan 2013). Acchuge Gowda pointed out to us that the state's management of BRT had, in fact, resulted in the forest being degraded over time, i.e. it was no longer as 'valuable' and healthy. One major indicator that Soligas use to illustrate the decline of forest health is the prevalence in almost the entire tiger reserve of Lantana camara (henceforth Lantana), a plant that was introduced into India by the British in the early 19th century and that has now proliferated. For Soligas, Lantana is what might be called a disservice as it is a non-indigenous and invasive species, but in an economic valuation exercise such disservices are rarely calculated (Lele et al. 2013). Soligas, in fact, have over the last decade identified the suppression of their customary management practices such as early season burning of the forest floor and the collection of tubers as the main reason for the proliferation of Lantana (Rai et al. 2019). As Redford and Adams (2009: 786) argue, not all ecosystem functions provide services directly but they are of value to the ecosystem as a whole.

What Soligas pointed out through stories is that economic valuation could potentially dis-embed them from nature and provide a very decontextualized understanding of ecosystem services (Raymond et al. 2017). Descola (2013) argues that in many 'indigenous' societies the human-nature divide is a false one. Soligas reminded us of Descola's point by telling us they named, live in and worship the forest. A detailed effort was undertaken in 2008 to map the forest according to Soliga views of the landscape (Rai and Madegowda 2017). On their map, Soligas identified nearly 500 cultural sites and 46 clan areas that they call yelle. Soligas belong to six different clans, each of which have several yelle in the forest. Within each yelle, there are sites known as Devaru (god), Maramma (female deity), Kallu gudi (shrine for interning the dead), Veeru (hero stone) and Habbi (spring). These sites dot the landscape that is currently administered as the tiger reserve. Soligas orally map the yelle, and sites within them, through naming each patch of forest, making for a landscape that is alive to the Soliga through naming, stories and songs. The 'counter-map' of BRT reflects a cultural as well as ecological landscape that Soligas have produced, but which the state appropriated for conservation. For Soligas the yelle is not a territorial area but a cultural one. The recent turn by the state to territoriality has resulted in some confusion amongst the Soligas regarding their relationship to the yelles. During discussions in 2008 a few Soliga were wary of mapping the extent of the yelles, concerned that clans with smaller ones would be at a disadvantage. The concept of territory, just as with value, is a new and confusing idea. As one Soliga, referring to the forest, told us: "this is not a factory but a farmer's field - this is nature. It is not proper to put a value on nature. How do you value the rocks, the mud, the 1,000 years of the hill?" (Muthugadagadde Podu, 23 September 2017).

The idea of nature and society being closely enmeshed was brought home most powerfully by another Soliga man, Dasegowda, in his recounting of the story of how their Lord Madeshwara killed Shravana, an evil but powerful king. In this story, Madeshwara assumed the form of a dancer and enticed the king to a polished rock and killed him as he slipped and fell. Even as everyone celebrated the death of the king, Madeshwara instructed Soligas to conduct Shravana's last rites every year, for he was after all a powerful king. The Soliga have done so ever since. Dasegowda ended by saying that if Soligas were removed from this forest and could not conduct this ritual it would spell the death knell for wildlife and the forest. Such a vision of a shared history of the forest, animals and people is ignored in the metrics of economic valuation. Such stories are a strong reminder that the forest has been shaped and produced by the people who have lived, cultivated and worshipped in it for years. Their appreciation of forest value is difficult to capture in economic terms. Economic valuation reduces these historical and cultural landscapes to possible commodities that can be invested in and traded, oblivious to the multiple values of other actors. 


\section{Valuation, neoliberalism and local communities}

Despite Soliga counter-narratives about protected area management, there is little sign that institutional changes to tiger conservation are likely to take place in the near future. In fact, the opposite is more probable, namely the expansion of inviolate tiger reserves. The protected area model has increasingly been neoliberalized with private actors (individual and corporate institutions) investing in tiger conservation. In India, NDTV joined hands with Aircel in 2010 in a 'Save Our Tigers Campaign', a campaign that a number of celebrities contributed to both financially and by lending their name to the cause. While this joint campaign is no longer active, tiger conservation is increasingly becoming a public-private partnership. It is also becoming increasingly 'technical' with little debate about managerial alternatives; rather it is about investing financially to ensure forest staff are better paid and equipped and that the Forest Department has better technology to monitor activities in the reserves (http://tiger.ndtv.com/aboutourcampaign.aspx).

The Verma Report (2015) builds on this economic logic. As we have already illustrated, it makes a case for valuation so as to capture the total economic value of tiger reserves as well as the likely benefits for human well-being. The third justification for valuation in the report is that tiger conservation generates investment benefits. In their companion article to the report, Verma et al. (2017: 242) state "in terms of attractiveness for enhanced investment in these tiger reserves, the estimates show that the investment multiplier, i.e. the ratio of flow benefits to management costs for each tiger reserve, range from 200 to 530." Through the use of this 'investment multiplier', the authors make the case that investing in natural capital is financially worthwhile.

An equally important question in the context of tiger reserves in India is the relationship between neoliberal conservation and enclosure. In a chapter titled 'Cost of inaction: Recreating a tiger reserve', the Verma Report lays to rest any doubts we may have about this question. They assess what it would cost to establish a tiger reserve. The main costs involved are land acquisition, rehabilitation, resettlement and habitat development. They show that these costs are 'astronomical' at Rs. 491,800 million (approx US\$6.9m) for a $1,069 \mathrm{~km}^{2}$ reserve or Rs. 4.62 million (US\$64,000) per hectare. They demonstrate that the state needs to protect existing tiger reserves so as to avoid having to create new ones. It should not be lost on anyone that the authors are using valuation to intensify conservation in existing enclosures, even as they suggest ways to fund the creation of new reserves. They offer just such a suggestion through a 'willingness to pay' analysis and arrive at an estimate of Rs. 141 (US\$2) for five years as a supplement on electricity bills to create such a fund. The application of such economic approaches to conservation issues is deeply political, and yet this is not discussed adequately outside the institutions that produce these estimates.

Valuation must be seen in this context. Fletcher and Büscher (2017) argue that the very nature of the valuation and ecosystem services logic makes it 'neoliberal.' Ecosystem services are made legible so that they can be commodified and privatized. Markets already exist in India for carbon trading. Nature tourism is expanding around protected areas. Yet as Kallis et al. state, imagining nature as a set of ecosystem services "does not necessarily pre-empt their commodification and enclosure" (2013: 100). While that might be true, we need also heed Milne and Adams who state "the significance of the PES policy model lies in the political and social effects of its design and implementation, not in its functioning as a market per se" (2012: 136). This suggests that even in the absence of eventual commodification, the valuation of ecosystem services will enable state and private actors to territorialize, enclose, make propertied and control areas. Matulis similarly warns of "the implications that engaging such mechanisms has in the progression of capitalist ideals and mentalities regardless of the immediate material outcomes" (2015: 1). These ideological critiques stem from a more basic ontological concern that "economic arguments about services valued by humans will overwrite and outweigh non-economic justifications for conservation" (Redford and Adams 2009: 785).

Even if we were to set aside these concerns, equally important to ascertain is who might benefit from the valuation and potential commodification of services. At the moment the beneficiaries are the state, the Forest Department and non-local investors such as tourism operators. Local people are not included despite the claims that they will be benefiting through forest produce harvest. Even promises of sharing tourism revenue with villagers, such as a Rs. 100 (US\$1.4) supplement that is levied on each jeep that the Forest Department operates for tourists in BRT has not been realized. This money has accumulated over ten years but has not been adequately disbursed to the village that is closest to the tourism complex as promised. This raises troubling 
questions about how local people can benefit from economic valuation within what remains largely a fortress conservation type model. Other concerns are perhaps even more fundamental. For example, if ecotourism picks up, how do we assess the 'benefits' of it if Soligas only benefit from marginal employment or through the marketing of their 'tribal' culture to tourists? Both are already happening in the BRT Hills, which begs the question as to what more economic valuation might do for Soligas? Finally, while there is little evidence that neoliberal conservation has resulted in significant capital accumulation locally (Dempsey and Suarez 2016), valuation might eventually attract more private sector players to invest in tiger conservation in the hopes of capital accumulation that might result from the marketization of such services as carbon and tourism. It might therefore be a way to gain political and discursive control of future protected area management.

In addition, valuation of ecosystem services could affect original conservation goals. We have already pointed to the danger of conservation being increasingly seen through the lens of economic benefits. We have also highlighted how nature will be made legible in particular ways, freezing nature as it is and undermining alternative imaginations of the forest landscape. Moreover, a look at the value of the stocks and flows shows us that the stock benefits (standing stock and carbon storage) are on average 20 times greater in value than the flows (employment generation, agriculture, fishing, fuelwood, fodder, timber, non-wood forest produce, genepool protection, carbon sequestration, water provisioning, water purification, sediment regulation/retention, nutrient cycling, biological control, moderation of extreme events, pollination, nursery functions, habitat refugia, cultural heritage, recreation, spiritual tourism, research, education and nature interpretation, gas regulation, and waste assimilation). It is worth recalling here that the main objective of tiger conservation is to increase the number of tigers. And yet valuation demonstrates that the highest estimates of monetary value are from timber and carbon stocks. Redford and Adams (2009) note that there is a danger economic valuation will tend to maximize single services over diverse landscapes and the 'original' landscapes that it seeks to (re)create.

Valuation, in other words, has the potential to alter ecosystem functions and structures by privileging certain services over others. For instance, the high value placed on sequestering carbon might change the original forest structure from a woodland savanna to a closed canopy forest. Extensive interviews with Soligas have helped us reconstruct the forest structure as it existed decades ago. The forest was managed as an open savanna woodland through the use of fire and with harvesting of tubers and other plants. State conservation practice has changed the forest to a more wooded one. Increasing stock benefits will affect the forest even more and could make the growing of trees more valuable than tiger conservation. There is therefore the possibility of the incommensurability between valuation of ecosystem services and the management of tigers and wildlife (Adams 2014).

\section{Why value a Tiger Reserve?}

Kallis et al. (2013), after synthesizing the political ecology and ecological economics literature on valuation, provide a guiding framework as to how to evaluate the monetary valuation of ecosystems. They list four questions that one should ask of any valuation effort:

(1) Will it improve the environmental conditions at stake?

(2) Will it reduce inequalities and redistribute power?

(3) Is it likely to suppress other languages of valuation and value-articulating institutions? and

(4) Will it serve processes of enclosure of the commons? (Kallis et al. 2013: 100)

We apply these questions to economic valuation of tiger reserves and BRT in particular and then ask whether they should be valued economically.

The question of whether valuation will improve environmental conditions might be answered by looking at what tiger reserves were set up to achieve. By all accounts and specifically those that have been provided by the NTCA, tiger conservation has been a success and tiger numbers have been increasing across the country. Tiger reserves have been established by central legislation and the denotification of these areas to other land uses has not easy to accomplish through legal means. It is unclear therefore what additional benefits valuation 
will bring to conservation of these landscapes, other than of course the possibility of generating additional revenue.

A more definitive answer might be provided for the question whether valuation will reduce inequalities and redistribute power. As we have described for BRT, and as a number of authors have shown elsewhere, tiger conservation has tended to increase inequalities and deprivation through the legal notification of inviolate tiger reserves that prevent any form of development activity within them (Bijoy 2011; Rai et al. 2018; Sen and Pattnaik 2017; Taghioff and Menon 2010). The Verma Report (2015) does not outline an approach to reduce these inequalities and all indications are that the flow of investments for conservation resulting from the monetization of services might increase inequality through curtailing access to services for local people and through the physical displacement of people from tiger reserves as required by law.

The Verma Report (2015) t acknowledges that some values, including cultural values, have not been accounted for and therefore might take a back seat. For example, Soliga cultural attachment to forests, the stories of their location in the forest and their historical connections to landscape are erased. Moreover, in the eyes of Soligas the transformations of the landscape over time have actually reduced the value of forests to them. This, they suggest, is the case because of the loss of their power to define management goals and pursue customary practices. Valuation therefore suppresses such accounts of change and local ideas of value, privileging other accounts of value that benefit others more.

Finally, does valuation encourage and facilitate the enclosure of forests in protected areas? In the Indian context, as in other parts of the world, most forests including protected areas are already enclosed. In 2006, the Wildlife (Protection) Amendment Act provided the legal framework to further enclose protected areas by expanding the core area of tiger reserves and making them inviolate. What valuation does, in this context, is to strengthen the case for enclosure by highlighting the current value of tiger reserves regardless of people's historical rights. This might prove to be problematic and a constraint for Soligas in a context where they have just been given individual and community rights to forests.

Following Kallis et al.'s scheme (2013), the answer to the question 'should we value tiger reserves in India?' would be a resounding 'No', at least in the current institutional context of fortress conservation. What then does one make of the current effort to value tiger reserves? Although we do not yet have adequate empirical information on the outcomes of their valuation, a historical, institutional and political assessment of the outcomes based on what we currently know of tiger conservation demonstrates that valuation is going to strengthen enclosure and increase the marginalization of forest dwellers.

\section{Conclusion}

We started this article by arguing that to understand neoliberal conservation or the governmentalizing of nature through the use of economic instruments, it is necessary as Bresnihan (2016) argues, to treat neoliberal conservation as a policy prescription aimed at resolving environmental problems so as to critique its logic and outcomes. Economists have promoted the economic valuation of ecosystem services, arguing that attaching an economic value to landscapes will show that they are more valuable than alternative land uses and therefore promote conservation, even as ecological arguments for conservation might fail. While policy makers have welcomed such valuation, seeing in it the possibility of conserving 'valuable' landscapes, political ecologists see in it a measure that promotes the same neoliberal logic that has produced environmental degradation in the first place and it is therefore a 'conceit' (Fletcher and Büscher 2017), or a way to implement selected political and social designs that benefit powerful actors (Milne and Adams 2012; Dempsey and Suarez 2016; Matulis 2015). We have added to these criticisms by talking about the many erasures that economic valuation of ecosystem services ensures. Valuation, we have argued, silences local voices, institutions and histories.

The institutional arrangements for the management of tiger reserves do not allow local residents to benefit from the services that accrue from these protected areas. What is needed is an overhaul of the structures of governance of these conservation fortresses. The state's role is central to this dismantling. Rather than invite corporate investments in conservation a true devolution of powers to local institutions and forest residents is a necessary first step. Most forest residents do not own land or assets that are essential for their development. A reliance on the flows from ecosystem services further entrenches their 'arborealisation', a term that Andrew 
Walker (2004) uses to denote the recasting of agricultural livelihoods as forest livelihoods. Valuation ignores this agrarian link that people have with the land even as they live within forests that are being accessed for services. Restoring these alienated relationships to land are essential to improving human well-being. The emphasis on ecosystem services as an approach to alleviating poverty and increasing human well-being is illplaced.

Valuation of nature only takes into account the views of people who consume nature and not the forest dwellers who produce these services through a history of transforming these landscapes through customary practice. Valuation of conservation landscapes, in this case of tiger reserves, has been conducted in the aftermath of a long history of disenfranchisement and is therefore unable to lead to the betterment and wellbeing of local people. We have described the history of such disenfranchisement of Soligas in BRT, adding to other such accounts from India. The continuing impact of a coercive conservation policy is now combined with valuation to possibly apply a further squeeze on local livelihoods. The valuation of tiger reserves is being done to attract investment into tiger conservation, and that valuation is therefore likely to instrumentally support the state-corporate nexus. Not only does valuation make space for corporate players in the conservation sector, it also strengthens the state's hands to continue its historical preserves and preoccupations. This could be troubling in a context where local communities have started to receive forest rights to address the historical injustices that they have faced.

Finally, valuation must be seen within the growing trend towards quantification, territorialization, monetization and commodification of nature as a response to environmental problems (Rasmussen and Lund 2018). Neoliberal conservation initiatives are in their nascent stage in India, a country that has had a long history of sovereign governmentality of nature conservation. Our analysis of one such neoliberal scheme for promoting an incentive structure for conservation through monetary valuation is therefore timely, as a market for these services have not yet formed (McElwee 2018). We hope that our discussion of the social and political impacts of valuation will discourage the adoption of valuation as a conservation strategy and help change course before these services are commodified - and it is too late to stem neoliberal conservation's appropriation of nature for the benefit of a few.

\section{References}

Adams, W.M. 2014. The value of valuing nature. Science 346(6209): 549-551.

Aggarwal, A. 2019. Neo-liberal conservation: analysing carbon forestry and its challenges in India. Economic and Political Weekly 54(16): 33-40.

Barnaud, C. and M. Antona. 2014. Deconstructing ecosystem services: uncertainties and controversies around a socially constructed concept. Geoforum 56: 113-123.

Bijoy, C. R. 2011. The great Indian tiger show. Economic and Political Weekly 46(4): 36-41.

Bresnihan, P. 2016. Transforming the fisheries: neoliberalism, nature, and the commons. Lincoln: University of Nebraska Press.

Büscher, B. 2012. Payments for ecosystem services as neoliberal conservation: (reinterpreting) evidence from the Maloti-Drakensberg, South Africa. Conservation and Society 10(1): 29-42.

Coffee Board. 2016. Tigers, elephants and Biligiris coffee. Indian Coffee Magazine 80(11-12): 31-34.

Dempsey, J. and D.C. Suarez. 2016. Arrested development? The promises and paradoxes of 'selling nature to save it'. Annals of the American Association of Geographers 106(3): 653-671.

Descola, P. 2013. Beyond nature and culture. Chicago: University of Chicago Press.

Fletcher, R. 2010. Neoliberal environmentality: Towards a poststructuralist political ecology of the conservation debate. Conservation and Society 8(3): 171-181.

Fletcher, R. and B. Büscher. 2017. The PES conceit: revisiting the relationship between payments for environmental services and neoliberal conservation. Ecological Economics 132: 224-231.

Gomez-Baggethun, E. and M. Ruiz-Perez. 2011. Economic valuation and the commodification of ecosystem services. Progress in Physical Geography 35: 613-628. 
Gowdy, J., C. Hall, K. Klitgaard and L. Krall. 2010. What every conservation biologist should know about economic theory. Conservation Biology 24(6): 1440-1447.

Huff, A. and C. Tonui. 2017. Making 'mangroves together': carbon, conservation and co-management in Gazi Bay, Kenya. STEPS Working Paper 95. Brighton: IDS.

Kallis, G., E. Gomez-Baggethun and C. Zografos. 2013. To value or not to value? That is not the question. Ecological Economics 94: 97-105.

Lele, S. and V. Srinivasan. 2013. Disaggregated economic impact analysis incorporating ecological and social trade-offs and techno-institutional context: a case from the Western Ghats of India. Ecological Economics 91: 98-112.

Lele, S., O. Springate-Baginski, R. Lakerveld, D. Deb and P. Dash. 2013. Ecosystem services: origins, contributions, pitfalls, and alternatives. Conservation and Society 11(4): 343-358.

Li, T.M. 2010. Indigeneity, capitalism, and the management of dispossession. Current Anthropology 51: 385414.

Lok Sabha. 2013. Unstarred question No. 5378. 29 April. Environment and forests on environment: Lok Sabha 2013-2014. Pp. 390-391. Available at: http://164.100.47.194/Loksabha/Questions/QResult15.aspx?qref=139633\&lsno=15(accessed 6 Nov. 2019).

NDTV Aircel http://tiger.ndtv.com/aboutourcampaign.aspx [Accessed on 15 August 2019]

Madegowda, C. 2009. Traditional knowledge and conservation. Economic and Political Weekly 44: 65-69.

Matulis, B.S. 2015. Valuing nature: a reply to Esteve Corbera. Ecological Economics 110: 158-160.

McCauley, D.J. 2006 Selling out on nature. Nature. 443(7): 27-28.

McElwee, P. 2017. The metrics of making ecosystem services. Environment and Society: Advances in Research 8(1): 96-124.

Millennium Ecosystem Assessment (MEA). 2005. Ecosystems and human well-being. Washington D.C.: Island Press.

Milne, S. and B. Adams. 2012. Market masquerades: uncovering the politics of community-level payments for environmental services in Cambodia. Development and Change 43(1): 133-158.

Munster, D. and U. Munster. 2012. Consuming the forest in an environment of crisis: nature tourism, forest conservation and neoliberal agriculture in south India. Development and Change 43(1): 205-227.

Ojha, H., T. Maraseni, A. Nightingale, B. Bhattarai and D. Khatri. 2019. Rescuing forests from the carbon trap. Forest Policy and Economics 101: 15-18.

Rasmussen, M.B. and C. Lund 2018. Reconfiguring frontier spaces: the territorialization of resource control. World Development 101: 388-399.

Rai, N.D. and C. Madegowda. 2017. Rethinking landscapes: history, culture and local knowledge in the Biligiri Rangaswamy Temple Tiger Reserve, India. In Bhagwat, S. (ed.). Conservation and development in India: reimagining wilderness. London: Routledge. Pp. 132-141.

Rai, N.D., T.A. Benjaminsen, S. Krishnan and C. Madegowda. 2019. Political ecology of tiger conservation in India: adverse effects of banning customary practices in a protected area. Singapore Journal of Tropical Geography 40(1): 124-139.

Raymond, C.M., M. Giusti and S. Barthel. 2017. An embodied perspective on the co-production of cultural ecosystem services: toward embodied ecosystems. Journal of Environmental Planning and Management 61(5-6): 778-799.

Rice B.L. 1897. Mysore: a gazetteer compiled for government. Volume 2. Mysore, by Districts. Westminster: Archibald Constable and Company.

Redford, K. H. and W. M. Adams 2009. Payment for ecosystem services and the challenge of saving nature. Conservation Biology 23(4): 785-787. 
Sen, A. and S. Pattnaik. 2017. How can traditional livelihoods find a place in contemporary conservation politics debates in India? Understanding community perspectives in Sundarban, West Bengal. Journal of Political Ecology 24: 861-880.

Taghioff, D. and A. Menon. 2010. Can a tiger change its stripes? The politics of conservation as translated in Mudumalai. Economic and Political Weekly 45(52): 69-76.

Verma, M., D. Negandhi, C. Khanna, A. Edgaonkar, A. David, G. Kadekodi, R. Costanza and R. Singh. 2015. Economic valuation of Tiger Reserves in India: a value + approach. Bhopal and New Delhi: Indian Institute of Forest Management and National Tiger Conservation Authority.

Verma, M. and D. Negandhi. 2018. Creating conservation value. Economic and Political Weekly 53(9): 4-5.

Verma, M., D. Negandhi, C. Khanna, A. Edgaonkar, A. David, G. Kadekodi, R. Costanza, R. Gopal, B.S. Bonal, S.P. Yadav and S. Kumar. 2017. Making the hidden visible: economic valuation of tiger reserves in India. Ecosystem Services 26: 236-244.

Walker, A. 2004. Seeing farmers for the trees: community forestry and the arborealisation of agriculture in northern Thailand. Asia Pacific Viewpoint 45(3): 311-324.

Wunder, S. 2005. Payments for environmental services: some nuts and bolts. Occasional Paper No. 42, Bogor Barat, Indonesia: Center for International Forestry Research. 